\title{
REPATRIATION ADJUSTMENT OF ACADEMICS: IS CO- WORKER SUPPORT A MATTER OF INFLUENCE
}

\author{
Robinson, J \\ Department of Human Resource Management, University of Jaffna, Sri Lanka \\ robinson435@gmail.com
}

\begin{abstract}
Over the last few decades, the literature on corporate repatriation has stressed the importance of effective management of repatriation and has highlighted the fact that unsuccessful management of repatriation leads to employees suffering from problems of adjustment which result in stress and loss of motivation at work. Literature highlights that coworker support help employees to get rid of their stress and establish certainty in an uncertain environment. However, co-workers' influence on repatriation adjustment has apparently been neither discussed nor empirically tested among academic repatriates so far. Given that, in this study researcher aims to find out the impact of academic repatriates' perceived co-worker support on repatriation adjustment. Data was collected from 102 Sri Lankan academic repatriates who had been attached to a foreign university or academic institution for more than one-year, had been involved in academic activities, and, at the survey date, had returned within the past four years. The data was analyzed using appropriate statistical tools. This study found that repatriates' perceived co-worker support had a positive impact on repatriation adjustment. Further, this study found repatriates' personal and situational variables has an influence on co-worker support but not on adjustment. The overall findings underline the essential role of co-worker in the adjustment process of academic repatriates. An in-depth discussion of findings, contributions, limitations, and implications for further research are presented.
\end{abstract}

Keywords: Repatriation, Adjustment, Co-worker support, Academics

\section{INTRODUCTION}

In recent years, an increasing number of academics view the international experience as an opportunity for career development and take steps to acquire such experience with the belief that this will increase their career prospects in their institution as well as in the global job market (Richardson \& Zikic, 2007). Also, universities consider providing an expatriate experience to academics is a long-term investment. Many universities invest large amounts of money to provide with international experience and to develop their talent pool.

In Sri Lanka, government and universities are very keen to upgrade their universities to reach a high international standard and meet 
national needs. Most importantly, the Sri Lankan government has attempted to increase the World University rankings of Sri Lankan universities. Sri Lankan universities' rankings were within the range from the 2092 (University of Colombo) to 15,362 (Uva Wellassa University) according to Webometrics 2016. In an attempt to get universities to reach international recognition and make Sri Lanka a global knowledge hub in Asia, the Sri Lankan government has continued to invest much money in the development of human capital (HETC, 2013; Samaranayake, 2011).

In Sri Lanka, Academics are encouraged by the government to gain international experience in research and teaching. The Sri Lankan government provides financial assistance for academics who want to engage in academic activities offshore for a specified period. Also, many international scholarships such as the Commonwealth Scholarship, the Australian Leadership Award and awards from the South Asian Association for Regional Cooperation (SAARC) are available for Sri Lankan academics who wish to pursue their research and higher studies overseas. Furthermore, a World Bank assisted project; "Higher Education for the Twenty-first Century" (HETC) also focuses on strengthening human resources in the higher education system by providing international experience to university academics (HETC, 2013). International experience is highly respected in Sri Lankan universities and is perceived as an opportunity to gain foreign exposure and experience. Perceived societal status increases with international experience and thus, in addition to the government motivation, individuals are themselves motivated to gain international experience.

In Sri Lanka, before academics leave the country, they need to sign an agreement with their university confirming that they will return to their home organization and serve for a particular period back at home university. Sri Lankan expatriates have strong family ties and are sentimental about their home country (Anas \& Wickremasinghe, 2010). Because of the bond agreement and family attachment, a reasonable number of academics return to their home university. People who return to their home countries after staying considerable time in abroad are called as repatriates.

Over the last few decades, the literature on corporate repatriation has stressed the importance of efficient management of repatriation, and has highlighted the fact that unsuccessful management of repatriation leads to employees suffering from problems of adjustment which result in stress and loss of motivation at work (Black, Gregersen, \& Mendenhall, 1992; Suutari \& Brewster, 2003). This situation leads to adverse consequences, for example, high turnover and low performance were observed among repatriates. 
Unsuccessful repatriation adjustment hampers the expectations of both organization and repatriates (Oddou, Osland, \& Blakeney, 2008). An ineffective repatriation management is a potential hurdle for retaining top talent and making use of this in the organization. This, in turn, hampers the successful process of internationalization of a university and its competitive position. Repatriates' unsatisfactory adjustment to their home organization can damage their personal and career development expectations.

For both an organization and repatriates, successful management of repatriation has become a challenge (Adler, 1981; Jassawalla, Connelly, \& Slojkowski, 2004; Shilling, 1993; Solomon, 1995). During their overseas stay, expatriates are most likely to change, and thus, upon repatriation they may feel they are in a new place, feel uncomfortable, and experience uncertainty (Black et al., 1992; Stroh et al., 2000). To feel comfortable, have a sense of certainty, and establish their position in the organization, repatriates need to socialize themselves to understand the prevailing situation and establish their position in their home organization. During the organizational socialization process, individuals (whether newcomers or repatriates) learn organizational values, formal and informal norms, politics, expected behaviour and essential social skills needed to be an accepted member of the organization (Louis, 1980b). This process helps individuals to adapt and integrate with the new organizational environment (Bauer, Bodner, Erdogan, Truxillo, \& Tucker, 2007; Chao et al., 1994; Cooper-Thomas \& Anderson, 2006).

The role of co-workers' social support has been seen as relevant to the socialization process. Theories such as work role transition theory (Nicholson, 1984), surprise and sense-making theory (Louis, 1980b), organizational socialization theory (Van Maanen \& Schein, 1979) and socialization resource theory (Saks \& Gruman, 2012) underline the role of social support from coworkers and supervisors in repatriates' adjustment to the new environment. Coworker support can minimize the adverse psychological effects of ongoing life strain and stressful events. In contrast to this need, the literature on repatriation of corporate employees speaks about the negative perception and unsupportive behaviour of repatriates' peers (Adler, 1981; Adler \& Gundersen, 2008). However, co-workers' influence on repatriation adjustment has apparently been neither discussed nor empirically tested among academic repatriates so far. Given that, in this study, researcher intended to find out does academic repatriates' perceived co-worker support predict repatriation adjustment? If yes, why and to what extent does co-worker support facilitate repatriation adjustment? If not, why? 


\section{LITERATURE REVIEW A ND HYPOTHESES DEVELOPMENT}

Repatriation is a transition from a host country to one's home country after living overseas for a significant period (Adler, 1981; O'Sullivan 2002). Repatriation of different groups of people, for example, students and peace corps volunteers, has been discussed in the literature many decades ago. Since the 1970s literature has been talking about repatriation of corporate employees (Adler 1981; Cagney, 1975; Howard, 1974). Research on repatriation of corporate employees has been developed from its research roots in domestic relocation and expatriation literature; theory on repatriation was developed based on the work of adjustment theorists of domestic relocation (Dawis \& Lofquist, 1984; Nicholson 1984) and expatriation (Black, Mendenhall \& Oddou, 1991).

Repatriation adjustment is a process of readjusting into the home context, having stayed overseas for a significant period (Adler, 1981; Allen \& Tavares, 1998). The process of repatriation adjustment continues until repatriates adjust adequately with different aspects of their home context (Sussman, 2000). In the process of repatriation adjustment repatriates attempt to reduce uncertainty and achieve a degree of fit with the different aspects of the home context (Black et al., 1992). Better adjusted repatriates feel acceptance, well-being, and a psychological comfort in the home context and better-fitted to the context (Adler, 1981; Black et al., 1992).

ss of re-adjusting into the home context, having stayed overseas for a significant period (Adler, 1981; Allen \& Tavares, 1998). The process of repatriation adjustment continues until repatriates adjust adequately with different aspects of their home context (Sussman, 2000). In the process of repatriation adjustment repatriates attempt to reduce uncertainty and achieve a degree of fit with the different aspects of the home context (Black et al., 1992). Better adjusted repatriates feel acceptance, well-being, and a psychological comfort in the home context and better-fitted to the context (Adler, 1981; Black et al., 1992).

Repartees realize mismatch between repatriates' repatriation expectations and the reality they experience upon their repatriation (Gregersen \& Black, 1995; Hurn, 1999; Stroh, 1995). This mismatch can be due to mainly the failure of expatriates to follow changes in the home organization during their absence and changes within expatriates and their failure to realize the changes occurring within themselves (Baughn, 1995; Hurn, 1999; Jassawalla et al., 2004; Martin \& Harrell, 1996; Stroh, 1998).

The expatriation context provided them with different stimuli that forced them to change themselves (Kohonen, 2004). The new alterations change their perception of themselves. In other words, expatriates 
change their identity (Baughn, 1995; Hall, 1968; Kohonen, 2004, 2008; Weigert, 1986) which can influence their attitudes, behavior, and perceptions. At the same time, the home organization can undergo substantial changes during their absence (Baughn, 1995; Jassawalla et al., 2004; Stroh, 1998). Changes are likely to take place in the home organization in the form of structural and policy changes, as well as changes in employees' positions; employees may have been promoted or a new member may have replaced a previous employee. These changes may alter the power structure of the informal organization. Repatriates fail to follow changes in the home organization and their failure to realize the changes occurring within themselves during their absence (Baughn, 1995; Hurn, 1999; Jassawalla et al., 2004; Martin \& Harrell, 1996; Stroh, 1998). Therefore, repatriates see the home context as unfamiliar, and they need to readjust and settle into that context (Adler, 1981; Allen \& Tavares, 1998; Lee \& Liu, 2007). Repatriates found re-adjustment to their home context was more painful and challenging than they expected and their expatriation adjustment (Adler, 1981; Wang, 1997). Repatriates experience psychological discomfort, alienation, uncertainties, and loss of control (Black et al., 1992; Vidal, Valle, \& Aragón, 2007).

\subsection{Coworker support and adjustment}

Co-workers are a vital part of the organization, and they define the social environment at work (Chiaburu \& Harrison,
2008). Co-workers can be concerned about the well-being of an employee as well as help in solving job-related problems (Ducharme, 2000). Co-workers provide supports such as task directing, mentoring, and a friendly environment. Particularly, when employees are in an uncertain environment co-worker can be an important source of resources (Chiaburu \& Harrison, 2008); they can provide necessary information about how to overcome the uncertainty and make sense of the environment. For example, when repatriates are unable to understand the workplace behavior and predict expected behavior, coworkers can provide information about how the formal and informal organization works and exactly what behaviors are expected from new employees. Such information enables repatriates to reduce uncertainty and make sense of the environment. Ducharme and Martin (2000) highlighted two types of co-worker support: affective support and instrumental support.

Repatriates returning to their home organization where they had been working previously need to undergo a socialization (re-socialization) process which includes learning the process and system, and readopting the organization's formal and informal norms and values (Oddou et al., 2008). Through the socialization process repatriates try to understand and acquire the behaviour and attitudes of the organizational members, and become an accepted member of the group. Repatriates take a time to socialize to the norms, values and customs of 
their home country culture (Sussman, 2000). The literature suggests that this process is usually painful and that support from others can reduce this pain, but that the attitudes and behaviors of organizational members may also make this process very painful and difficult.

In the repatriation context, repatriate experience co-workers' unsupportive behaviour (Adler, 1981; Adler \& Gundersen, 2008). Repatriates were perceived wrongly or negatively by their co-worker and were treated by them accordingly. Co-workers were not ready to accept repatriates' new identity, and undervalued their overseas experience (Adler, 1981). In Japan, repatriates were viewed as external members and given a new negative title "kokusaijin"an international person - (Hurn, 1999) which infers that the repatriates can be treated as outside members. A study by Gama and Pedersen (1977) among Brazilian returnees who returned from their graduate studies in the US found that returnees (university professors) experienced peers' professional jealousy. Peers may fear the repatriates as they feel that these repatriates have bettered themselves and their presence may hinder their own progress or threaten their existing status. Thus they are not ready to accept them. This behavioral issue is common in the organizational setting generally, but repatriates perceive it as a severe problem as they experience various adjustment issues upon their repatriation (Howard, 1974) and in turn, this may increases their difficulties in the process of adjustment.

In universities, academics are working together with least hierarchy and the greatest trust, and working in a team on projects. A senior academic is more likely to lead projects and junior academics work as a team and play different roles on a project (Baruch \& Hall, 2004). Thus, the support of co-workers has been crucial for academic repatriates to better understand the work, work environment, and get rid of repatriation stress and challenges. Hence, in line with the existing literature on repatriation and organizational socialization theory, researcher presume that academic repatriates' perceived co-worker support can enable them to adjust to their repatriation better.

$\mathbf{H}_{1}$ : Academic repatriates' perceived coworker support has a positive and significant impact on repatriation adjustment.

Co-worker may offer their support in many ways. Co-workers can help in solving their problems and concern their well being. Also, Co-workers provide supports such as task directing, mentoring and create a supportive climate. Particularly, when repatriates are in an uncertain environment co-worker may help to better understand the environment and to get rid of repatriates' stress. Ducharme and Martin (2000) highlighted two types of co-worker support: affective support and instrumental support. 
Affective support related to co-workers' care about other employees and make them feel that they are close with them. The instrumental support is related to co-workers support in task-related aspects such as be helpful in getting job done and providing useful advice on job-related problems. Therefore, researcher attempt to develop and test the following three hypotheses for two reasons: the first is to better understand the effect of each type of co-worker support and the second is to highlight if affective or instrumental support is more effective in the context of repatriation adjustment of academics.

$\mathbf{H}_{12}$. Academic repatriates' perceived affective co-worker support positively relates to repatriation adjustment.

$\mathbf{H}_{1 \mathrm{~b}}$. Academic repatriates' perceived instrumental co-worker support positively relates to repatriation adjustment.

$\mathbf{H}_{1 \mathbf{c}}$. Academic repatriates who perceive affective co-worker supports are better adjust to their repatriation than who perceive instrumental co-worker support.

\section{METHODOLOGY}

\subsection{Sample and Procedures}

This study focuses on Sri Lankan academic repatriates who had been attached to a foreign university or academic institution for more than one-year, had been involved in academic activities (teaching/research/ higher studies), and, at the survey date, had returned within the past four years. This study is a cross-sectional study using questionnaires.150 questionnaires were distributed to respondents by the researcher directly and through researcher's friends. Each questionnaire accompanied by a cover letter assuring confidentiality. The researcher sent reminders to respondents by mail, and ultimately researcher received 113 responses which were $75 \%$ of issued questionnaires. This response rate is higher than the average rate of $52.5 \%$ in organizational research (Baruch \& Holton, 2008). 11 questionnaires were rejected: five were rejected because of more than $15 \%$ missing values and six were rejected as respondents have less than one-year overseas experience. Ultimately this study used 102 respondents.

\subsection{Respondents' profile}

Table 1 shows respondents' profile. Male participants accounted for $54(53 \%)$ of the respondents and female for 48 (47\%). 85 repatriates, accounting for $84 \%$, were married. In terms of previous overseas experience, although 29 (28\%) respondents had at least one previous overseas experience, $73(72 \%)$ respondents had no such experience. 
Table 1: Respondents' profile

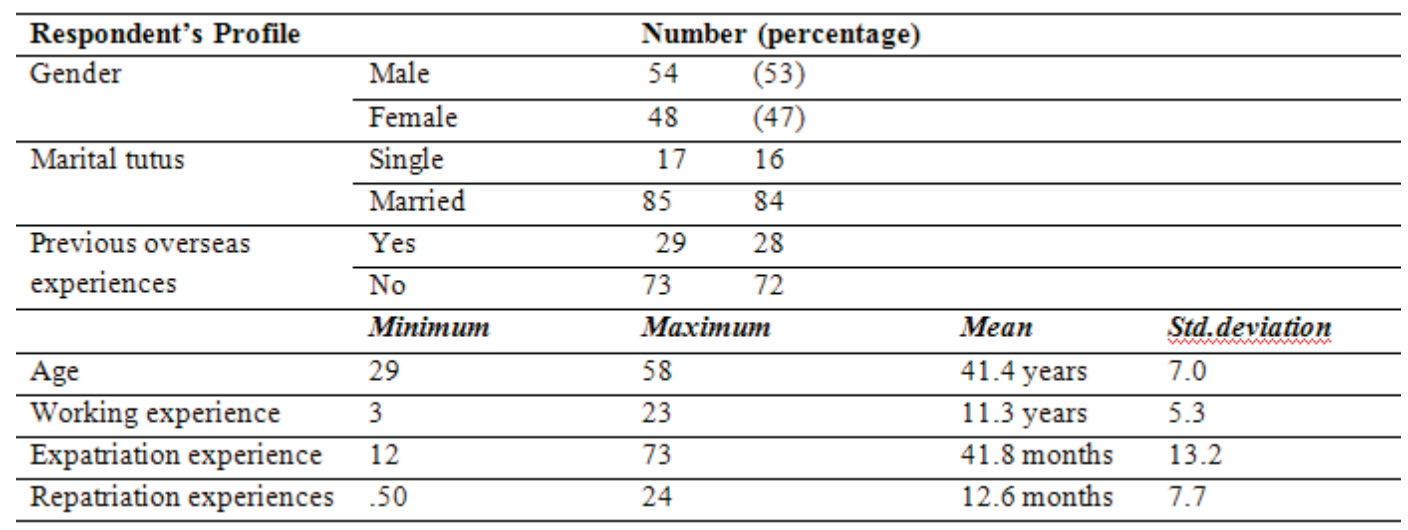

Note: Std.deviation $=$ Standard deviation In terms of age and working experience of respondents, their average age and working experience were 41.4 years and 11.3 years respectively, with a standard deviation of 7 years and 5.3 years respectively. Respondents' expatriation and repatriation experience were 41.8 months and 12.6 months respectively, with a standard deviation of 13.2 and 7.7 months respectively.

\subsection{Variables}

\section{Co-worker support}

Eight social support (co-worker support) items developed by Ducharme and Martin (2000) were included in the survey. This scale had an alpha of .78. These items focus on employees' perceptions of co-workers' support at the stressful situation in the organization. This instrument measured two types of co-worker support: affective support and instrumental support. The wording of the original items was modified without changing the meaning of the statements to make the respondents identify personally with the question.

\section{Adjustment}

Repatriation adjustment is a process of readjusting into the home context, having stayed overseas for a significant period (Adler, 1981; Allen \& Tavares, 1998). Better adjusted repatriates feel acceptance, wellbeing, and a psychological comfort in the organization context and better-fitted to the context (Adler, 1981; Black et al., 1992). To measure repatriates' adjustment researcher developed 5 item with Likert scale.

\section{Demographic and situational variables}

In addition to the above two research constructs, seven situational and personal variables were measured to describe the research sample. These variables were: gender, marital status, pervious overseas experience, age, working experience, overseas experience and repatriation experience 


\section{DATA ANALYSIS PROCEDURES}

First, the survey data were entered into a Microsoft Excel sheet and then transferred to SPSS 20 for data cleaning and analysis. First, researcher performed exploratory factor analysis (EFA) to (a) identify whether the same factors as found before were replicated, or whether new factors emerged than those anticipated in this study; (b) determine whether the measures included in the scales reasonably measured the construct in this study context. Further, T-test, correlation, and regression analysis were performed to analysis the data and test the hypothesis.

As the proposed survey was self-report and cross-sectional it may be vulnerable to common method variance (CMV) (Podsakoff \& Organ, 1986). Researcher took the necessary steps to minimize CMV issues in the survey at both the design stage and the analysis stage as suggested by Podsakoff et al. (2003).

\section{DATA ANALYSIS AND RESULTS}

\subsection{Analysis And Results}

Before conducting the analysis the accuracy of the data was checked; no values outside the specified range were found, means standard deviations and correlations appeared to be reasonable. Further, questionnaire non-responsive rate, item nonresponse rate, distribution of data and outliers were taken into account and treated properly.

Exploratory factor analysis (EFA) approach The researcher used the Principal axis factoring (PAF approach). PAF was performed with eigenvalues $>1$ extraction to identify the number of factors that emerged from the empirical data (Brown, 2006; Fabriger et al., 1999; Raubenheimer, 2004). The following five criteria were followed to identify the factor structure: (i) Bartlett's test of sphericity $(\mathrm{p}<0.05)$; (ii) the KaiserMeyer-Olkin (KMO) measure of sampling adequacy (>.6); (iii) factor loadings (>.4) (cross loading also analyzed to provide theoretical and empirical lights); (iv) eigenvalues (>1); and (v) Cronbach's alpha values $(>.7)$.

Table 2: Exploratory factor analysis (EFA) approach

\begin{tabular}{|c|c|c|c|}
\hline Factor & Items & $\begin{array}{l}\text { Co-worker } \\
\text { support }\end{array}$ & Adjustment \\
\hline \multirow{8}{*}{$\begin{array}{l}\text { Co-worker } \\
\text { support }\end{array}$} & CWS-1 & .70 & .26 \\
\hline & CWS-2 & .73 & .31 \\
\hline & CWS-3 & .78 & .14 \\
\hline & CWS-4 & .75 & .28 \\
\hline & CWS-5 & .79 & .20 \\
\hline & CWS-6 & .81 & .19 \\
\hline & CWS-7 & .84 & .16 \\
\hline & CWS-8 & .73 & .18 \\
\hline \multirow[t]{5}{*}{ Adjustment } & Adj-1 & .20 & .86 \\
\hline & Adj -2 & .23 & .88 \\
\hline & Adj -3 & .25 & .90 \\
\hline & Adj -4 & .31 & .70 \\
\hline & Adj-5 & .13 & .72 \\
\hline \multicolumn{4}{|c|}{$\begin{array}{lll}\text { Eigenvalues } 7.12 .3 & 2.0\end{array}$} \\
\hline Cronbach's a & & .93 & .92 \\
\hline \multicolumn{4}{|c|}{$\begin{array}{l}\text { Variance explained; Total } 68 \%, \mathrm{KMO}, .84 \text {. } \\
\text { Bartlett's Test Sig } .000\end{array}$} \\
\hline \multicolumn{4}{|c|}{$\begin{array}{l}\text { The results showed that two factors emerged } \\
\text { with eigen values greater than } 1 \text {. The Kaiser- } \\
\text { Meyer-Olkin Measure of Sampling }\end{array}$} \\
\hline
\end{tabular}


Adequacy was .84, Bartlett's Test of Sphericity $\mathrm{p}<0.05$. Loadings of all variables with related factors were greater than .70, and no cross-loadings more than .32 were found. Cronbach's alpha value was satisfactory for each factor, at .93 and .92 for co-worker support and adjustment respectively.

It was expected that co-worker support as two factors: an affective support and instrumental support, but EFA supported that co-worker support as one factor. Though, Ducharme and Martin's (2000) divided co-worker support as two component the item included in their survey were quite similar, and respondents of the present study did not find the differences between affective and instrumental component of co-worker support in this study context. Further, when researcher fixed the model with three factors (adjustment, affective support and instrumental support) the EFA result did not satisfy most of the evaluation criteria. Based on the EFA results, the researcher decided to consider co-worker support as one factor in this study. As in this study context, coworker support emerged as one factor the researcher was unable to test the rest of the three proposed hypothesis (H1a, H1b and H1c).

The EFA confirmed that perceived coworker support is one factor, no new factors emerged than those anticipated in this study; and the measures included in the scales reasonably measured the construct in this study context.

To test if respondents' personal and situational variables' influence on the independent and dependent variable, t-test (for categorical variables) and correlation analysis were performed and the results were tabulated in the table below. A T-test was performed to identify if there is significant differences in adjustment and co-worker support between respondents' gender and marital status. Correlation was performed to identify if there is any significant relationship between respondents' variables (age, working expense, expatriation experience and repatriation experience) and research variables (co-worker support and adjustment)

Table 3: Respondents' profile and research variables

\begin{tabular}{|c|c|c|c|c|c|c|c|}
\hline \multirow{2}{*}{\multicolumn{2}{|c|}{$\begin{array}{l}\text { Respondents' Personal } \\
\text { variable }\end{array}$}} & \multicolumn{3}{|c|}{ Co-worker support } & \multicolumn{3}{|c|}{ Adjustment } \\
\hline & & Mean & Std & Sig. $95 \%$ & Mean & Std & Sig \\
\hline \multirow[t]{2}{*}{ Gender } & Male & 4.92 & 1.04 & \multirow[b]{2}{*}{ Sig. } & 3.54 & 1.23 & \multirow[b]{2}{*}{ Not Sig } \\
\hline & Female & 5.40 & 1.05 & & 4.09 & 1.57 & \\
\hline \multirow{2}{*}{$\begin{array}{l}\text { Marital } \\
\text { status }\end{array}$} & Single & 5.54 & .71 & \multirow[b]{2}{*}{ Sig. } & 3.38 & 1.69 & \multirow[b]{2}{*}{ Not Sig } \\
\hline & Married & 5.04 & 1.12 & & 3.90 & 1.34 & \\
\hline \multirow{2}{*}{$\begin{array}{l}\text { Previous } \\
\text { overseas } \\
\text { experience }\end{array}$} & Yes & 5.44 & .78 & \multirow[b]{2}{*}{ Sig } & 4.11 & 1.43 & \multirow[b]{2}{*}{ Not Sig } \\
\hline & No & 4.98 & 1.17 & & 3.63 & 1.39 & \\
\hline
\end{tabular}


T-test result indicates that there are no significant differences in perceived coworker support between male and female, married and unmarried, as well as repatriates with and without previous overseas experience. But, significant differences were not observed on adjustment between male and female, married and unmarried as well as repatriates with and without previous overseas experience.

According the correlation analysis (Table 4) no significant relationships were observed between repatriates personal variables (age, working experience, period of overseas assignment and time returned) and coworker support or adjustment.

Table 4: Relationship between respondents' profile and research variables

\begin{tabular}{lcc}
\hline Respondents' profile & $\begin{array}{c}\text { Co-worker } \\
\text { support }\end{array}$ & Adjustment \\
\hline Age & -.062 & -.038 \\
\hline $\begin{array}{l}\text { working experience at home } \\
\text { University }\end{array}$ & -.101 & .007 \\
\hline Period of overseas assignment & -.188 & .081 \\
\hline Time since returned & .048 & .026 \\
\hline
\end{tabular}

The t-test and correlation analysis results showed that the repatriation adjustment was not influenced by repatriates personal and situational variables. In other words, the degree of repatriation adjustment is influenced by some variables other than the repatriate's personal and situational variables.

\subsection{Hypothesis testing}

To test the impact of co-worker support on adjustment, researcher performed regression analysis. Adjustment and coworker support were entered as dependent and independent variables respectively. The results showed that co-worker support have a positive impact $\left(486^{* *}\right)$ on repatriation adjustment. The results further explained that coworker support explains $24 \%\left(\mathrm{R}^{2}\right.$ .236) of the variance of the model.

In this study researcher proposed that repatriates' perceived co-worker support positively predicted their repatriation adjustment. The results show that coworker support was a significant predictor $(=$ $0.486, p<0.05$ ) of repatriation adjustment. It suggests that co-worker support during the repatriation help repatriates adjust to their repatriation better, and thus the hypothesis supported for academic repatriates.

\section{DISCUSSION AND CONCLUSION}

In line with the proposed hypothesis, results found that repatriates who perceive high coworker support will adjust to their repatriation better. This finding is consistent with existing literature. Repatriation creates psychological discomfort and high levels of stress (Black, 1988; Nicholson, 1984; Suss man, 2001). According to organizational socialization theory co-workers' support is a valuable resource that facilitates repatriation adjustment by enabling repatriates to learn the repatriation context, make sense of the situation, and reduce uncertainty. Scholars 
consistently suggested that supportive relationships were the resources that facilitate employees to deal with stressful events (Bakker \& Demerouti, 2007; Saks \& Gruman, 2012; Viswesvaran et al., 1999). Similar to this idea, in a study among insurance company workers Karademas (2006) found that social support increases workers' psychological capital (optimism and self-efficacy). Consistent with these views, my results suggest that when repatriates are supported by their co-workers they are able to adjust better.

This finding suggests that repatriates expect their co-workers need to be close, and really care about them (Cohen \& Wills, 1985). Also, they expect co-workers' assistance in work-related issues (Caplan et al., 1975). However, literature on corporate repatriates highlights co-workers were unsupportive and were not ready to accept repatriates' new identity (behaviors), were reluctant to value their overseas experience (Adler \& Gundersen, 2008), and treated them as external members (Hurn, 1999). For this reason, the role of the organization becomes more necessary to create an organizational climate that motivates existing employees to be supportive to repatriating colleges instead of being unsupportive.

When co-workers are unsupportive to repatriates, in the first stage, organizations need to understand the causes of co-workers' unsupportive behavior towards repatriates. If co-workers not providing support to repatriates because they feel repatriates are a threat to their present status and their future career advancement in the organization, HR need to make sure, if possible, that repatriates' arrival never affects existing employees' career advancement opportunities. If co-workers' lack of support is due to misunderstanding of repatriates' behavior and attitudes, organizations need to take the necessary steps to explain to existing employees the fact that repatriates are not the same person as they were when they left, and that changes in attitudes and behavior in repatriates are a natural part of a long-term overseas stay.

Moreover, this study contributes to the repatriation literature by examining the impact of co-worker support on repatriation adjustment of academics, and by providing initial empirical evidence of the impact of co-worker support on repatriation adjustment with the academic repatriates' sample.

In addition to answering the research questions, my research has put forward new questions in need of further investigation. This study found that personal and situational variables influence perceived coworker support; therefore, there is a need for further research to understand the factors determining repatriates perceived co-worker support to facilitate repatriates to better adjust their repatriation. Further to understand the complex nature of the repatriation adjustment all related variables, 
for example, organization support, repatriates' initiatives and cultural adaptation need to be included into the model and analyzed simultaneously using SEM. Also, adopting longitudinal approach in repatriation adjustment research facilitate to better understand the nature of repatriation and its predictor.

\section{REFERENCES}

Adler, N. J. (1981). Re-entry: Managing cross-cultural transitions. Group \& Organization Management, 6(3), 341356.

Adler, N. J., \& Gundersen, A. (2008). International dimensions of organizational behaviour. Mason, Ohio: South-Western Pub.

Allen, T. D., McManus, S. E., \& Russell, J. E. A. (1999). Newcomer socialization and stress: Formal peer relationships as a source of support. Journal of Vocational Behavior, 54(3), 453-470.

Anas, M. U. M., \& Wickremasinghe, S. I. (2010). Brain drain of the scientific community of developing countries: The case of Sri Lanka. Science and Public Policy, 37(5), 381-388.

Bakker, A. B., \& Demerouti, E. (2007). The job demands-resources model: State of the art. Journal of Managerial Psychology 22(3), 309-328.
Baruch, Y., \& Holtom, B. C. (2008). Survey response rate levels and trends in organizational research. Human Relations, 61(8), 1139-1160.

Baughn, C. (1995). Personal and organizational factors associated with effective repatriation. In J. Selmer (Ed.), Expatriate management: New ideas for international Business, (pp. 215-230). Westport.

Bauer, T. N., Bodner, T., Erdogan, B., Truxillo, D. M., \& Tucker, J. S. (2007). Newcomer adjustment during organizational socialization: A metaanalytic review of antecedents, outcomes, and methods. Journal of Applied Psychology, 92(3), 707-721.

Black, J. S. (1992). Coming Home: Therelationship of expatriate expectations with repatriation adjustment and job performance. Human Relations, 45(2), 177-192.

Black, J. S. (1992). Socializing American expatriate managers overseas tactics, tenure, and role innovation. Group \& Organization Management, 17(2), 171-192.

Black, J. S. (1994). O Kaerinasai: Factors related to japanese repatriation adjustment. Human Relations, 47(12), 1489-1508. 
Black, J. S., \& Ashford, S. J. (1995). Fitting in or making jobs fit: Factors affecting mode of adjustment for new hires. Human Relations, 48(4), 421-437.

Black, J. S., \& Gregersen, H. B. (1991a). Antecedents to cross-cultural adjustment for expatriates in Pacific Rim assignments. Human relations, 44(5), 497-515.

Black, J. S., \& Gregersen, H. B. (1991b). When Yankee comes home: Factors related to expatriate and spouse repatriation adjustment. Journal of International Business Studies, 22(4) 671-694.

Black, J. S., \& Gregersen, H. B. (1999). So you're coming home. Global Business Pub.

Black, J. S., \& Stephens, G. K. (1989). The influence of the spouse on American expatriate adjustment and intent to stay in Pacific Rim overseas assignments. Journal of Management, 15(4), 529544.

Black, J. S., Gregersen, H. B., \& Mendenhall, M. E. (1992). Toward a theoretical framework of repatriation adjustment. Journal of International Business Studies, 23(4), 737-760.

Brown, T. A. (2006). Confirmatory factor analysis for applied research. New
York, NY: Guilford.

Caplan, R. D., Cobb, S., \& French, J. R. (1975). Relationships of cessation of smoking with job stress, personality, and social support. Journal of applied psychology, 60(2), 211.

Cable, D. M., \& DeRue, D. S. (2002). The convergent and discriminant validity of subjective fit perceptions. Journal of Applied Psychology, 87(5), 875.

Cagney, W. F. (1975). Executive reentry: The problems of repatriation. Personnel Journal 54(9), 487-488.

Cable, D. M., \& Judge, T. A. (1996). PersonOrganization fit, job choice decisions, and organizational entry. Organizational Behavior and Human Decision Processes, 67(3), 294-311.

Chao, G. T., O'Leary-Kelly, A. M., Wolf, S., Klein, H. J., \& Gardner, P. D. (1994). Organizational socialization: Its content and consequences. Journal of Applied Psychology, 79(5), 730.

Cohen, S., \& Wills, T. A. (1985). Stress, social support, and the buffering hypothesis. Psychological Bulletin, 98(2), 310-357.

Cooper-Thomas, H. D., \& Anderson, N. (2006). Organizational socialization: A new theoretical model and 
recommendations for future research and HRM practices in organizations. Journal of Managerial Psychology, 21(5), 492-516.

Dawis, R. V., \& Lofquist, L. H. (1978). A note on the dynamics of work adjustment. Journal of Vocational Behavior, 12(1), 76-79.

Fabrigar, L. R., Wegener, D. T., MacCallum, R. C., \& Strahan, E. J. (1999). Evaluating the use of exploratory factor analysis in psychological research. Psychological Methods, 4(3), 272-299

HETC. (2013). Higher Education for the Twenty-first Century (HETC) Project Retrieved 10/03/2013, from http://www.hetc.lk/

Chiaburu, D. S., \& Harrison, D. A. (2008). Do peers make the place? Conceptual synthesis and meta-analysis of coworker effects on perceptions, attitudes, OCBs, and performance. Journal of Applied Psychology, 93(5), 1082.

Hurn, B. J. (1999). Repatriation the toughest assignment of all. Industrial and Commercial Training, 31(6), 224228.
United States. International Journal of Intercultural Relations, 1(4), 46-59.

Jassawalla, A., \& Sashittal, H. C. (2011). Integrating Repatriated Managers in MNCs. In S. Mariano, M. Mohamed, P.Ghauri, Q. Mohiuddin (Eds.) The Role of Expatriates in MNCs Knowledge Mobilization (pp. 113130). Emerald Group Publishing Limited.

Jassawalla, A., Connelly, T., \& Slojkowski, L. (2004). Issues of effective repatriation: A model and managerial implications. SAM Advanced Management Journal, 69(2), 38-46.

Kohonen, E. (2008). The impact of international assignments on expatriates' identity and career aspirations: Reflections upon re-entry. Scandinavian Journal of Management, 24(4), 320-329.

Lorange, P. (2006). A performance- based, minimalist human resource management approach in business schools. Human Resource Management, 45(4), 649-658.

Louis, M. R. (1980a). Career transitions: Varieties and commonalities. Academy of Management Review, 5(3)329-340.

Louis, M. R. (1980b). Surprise and sense making: What newcomers experience in entering unfamiliar organizational 
settings. Administrative Science Quarterly, 25(2), 226-251.

Martin, J. N., \& Harrell, T. (1996). Reentry training for intercultural sojourners. Handbook of intercultural training, 2, 307-326.

Nicholson, N. (1984). A theory of work role transitions. Administrative Science Quarterly, 29(2), 172-191.

Oddou, G., Osland, J. S., \& Blakeney, R. N. (2008). Repatriating knowledge: Variables influencing the "transfer" process. Journal of International Business Studies, 40(2), 181-199.

O'Sullivan, S. L. (2002). The protean approach to managing repatriation transitions. International Journal of Manpower, 23(7), 597-616.

Podsakoff, P. M., \& Organ, D. W. (1986). Self-reports in organizational research: Problems and prospects. Journal of Management, 12(4), 531-544.

Podsakoff, P. M., MacKenzie, S. B., Lee, J. Y., \& Podsakoff, N. P. (2003). Common method biases in behavioral research: A critical review of the literature and recommended remedies. Journal of Applied Psychology, 88(5), 879-903.

Raubenheimer, J. (2004). An item selection procedure to maximize scale reliability and validity. SA Journal of Industrial
Psychology, 30(4), 59-64.

Richardson, J., \& McKenna, S. (2003). International experience and academic careers: What do academics have to say? Personnel Review, 32(6), 774795.

Saks, A. M., \& Ashforth, B. E. (1997). Organizational socialization: Making sense of the past and present as a prologue for the future. Journal of Vocational Behavior, 51(2), 234-279.

Saks, A. M., \& Ashforth, B. E. (2000). The role of dispositions, entry stressors, and behavioral plasticity theory in predicting newcomers' adjustment to work. Journal of Organizational Behavior, 21(1), 43-62.

Saks, A. M., \& Gruman, J. A. (2012). Getting newcomers on board: A review of socialization practices and introduction to socialization resources theory. In C. Wanberg (Ed.), The Oxford Handbook of Organizational Socialization (pp 2755). New York: Oxford University Press Inc.

Saks, A. M., Gruman, J. A., \& CooperThomas, H. (2011). The neglected role of proactive behavior and outcomes in newcomer socialization. Journal of Vocational Behavior, 79(1), 36-46.

Saks, A. M., Uggerslev, K. L., \& Fassina, N. 
E. (2007). Socialization tactics and newcomer adjustment: A meta-analytic review and test of a model. Journal of Vocational Behavior, 70(3), 413-446.

Samaranayake, G. (2011). Corporate plan 2011-201. Sri Lanka: University Grants Commission.

Shilling, M. (1993). How to win at repatriation. Personnel Journal, 72(9), 40-46.

Solomon, C. M. (1995). Repatriation: Up, down or out? Personnel JournalBaltimore Then Costa Mesa, 74, 28-28.

Stroh, L. K., Gregersen, H. B., \& Black, J. S. (1998). Closing the gap: Expectations versus reality among repatriates. Journal of World Business, 33(2), 111124.

Stroh, L. K., Gregersen, H. B., \& Black, J. S. (2000). Triumphs and tragedies: Expectations and commitments upon repatriation. International Journal of Human Resource Management, 11(4), 681-697.

Sussman, N. M. (2001). Repatriation transitions: Psychological preparedness, cultural identity, and attributions among American managers. International Journal of Intercultural Relations, 25(2), 109123.
Suutari, V., \& Brewster, C. (2003). Repatriation: Empirical evidence from a longitudinal study of careers and expectations among Finnish expatriates. International Journal of Human Resource Management, 14(7), 1132-1151.

Suutari, V., \& Välimaa, K. (2002). Antecedents of repatriation adjustment: New evidence from Finnish repatriates. Iternational Journal of Manpower, 23(7), 617-634.

Szkudlarek, B. (2010). Reentry-A review of the literature. International Journal of Intercultural Relations, 34(1), 1-21.

van den Brink, M., Fruytier, B., \& Thunnissen, M. (2013). Talent management in academia: Performance systems and HRM policies. Human Resource Management Journal, 23(2), 180-195.

Van Maanen, J., \& Schein, E. H. (1979). Toward a theory of organizational socialization. In B. M. Staw (Ed.), Research for organizational behavior (pp. 209-264). Greenwich, CT: JAI Press.

Vidal, M. E. S., Valle, R. S., \& Aragón, M. I. B. (2007). The adjustment process of Spanish repatriates: A case study. The International Journal of Human Resource Management, 18(8), 13961417. 
Vidal, M. E. S., Valle, R. S., \& Aragón, M. I. Wang, M. J. (1997). Reentry and reverse B. (2008). International workers' satisfaction with the repatriation process. The International Journal of Human Resource Management, 19(9), 1683-1702. culture shock. In Cushner. K., \& Brislin, R.W. (Eds.), Improving intercultural interactions: Modules for Cross- Cultural Training Programs (pp. 109- 28). London: Sage, London.

Viswesvaran, C., Sanchez, J. I., \& Fisher, J. Weigert, A., Teitge, J. S., \& Teitge, D. W. (1999). The role of social support in the process of work stress: A metaanalysis. Journal of Vocational Behavior, 54 (2), 314-334. (1986). Society and identity: Toward a sociological psychology. Cambridge: Cambridge UniversityPress. 